\title{
PENGARUH KONSENTRASI KECAMBAH KACANG HIJAU TERHADAP SIFAT FISIK DAN KIMIA TEPUNG TALAS KIMPUL
}

\author{
[The Effect of Mung Bean Sprout Concentration on the Physical and \\ Chemical Properties of Taro Flour]
}

\author{
Hariyadi, Zainuri*, Yeni Sulastri \\ Program Studi Ilmu dan Teknologi Pangan, Fakultas Teknologi Pangan dan Agroindustri \\ Universitas Mataram \\ *Email: nzainuri2@gmail.com, zainuri.ftp@unram.ac.id
}

Diterima 26 Februari 2020 / Disetujui 9 Juli 2020

\begin{abstract}
This study aims to find out the effect of mung bean sprout concentration on the physical and chemical properties of taro flour. The method used in this research was experimental method and was designed using Completely Randomized Design with a single factor experiment (the concentration of mung bean sprouts). There were 5 treatments (0\%, 10\%, 20\%, 30\% and $40 \%$ of mung bean sprouts), and each treatment were made into 4 replications. Data from the observations were analyzed using analysis of Variance (ANOVA) at 5\% significant level using Co-Stat software. If there was significant difference, the data were further tested using the Honest Real Difference test at 5\% significant level too. The results showed that the addition of mung bean sprout extract significantly affected the moisture content, protein content, ash content and oxalate content of taro flour. The treatment of $40 \%$ mung bean sprout extract is recommended as the best treatment for moisture content (10.53\%), ash content (5.24\%), protein content (3.84\%), calcium oxalate content $(0.0268 \%)$, water absorption $(87.42 \%)$, and $L$ value $(88.14)$ of modified taro flour.
\end{abstract}

Keywords: flour, taro, enzymes, mung bean sprouts

\begin{abstract}
ABSTRAK
Tujuan penelitian ini adalah untuk mengetahui pengaruh konsentrasi kecambah kacang hijau terhadap sifat fisik dan kimia tepung talas kimpul. Metode yang digunakan dalam penelitian ini adalah metode eksperimental dan dirancang menggunakan Rancangan Acak Lengkap (RAL) dengan faktor tunggal (konsentrasi kecambah kacang hijau). Terdapat 5 perlakuan (konsentrasi $0 \%, 10 \%, 20 \%, 30 \%$ dan $40 \%$ kecambah kacang hijau), dan tiap perlakuan dibuat 4 ulangan. Data hasil pengamatan dianalisis dengan menggunakan analisis keragaman pada taraf nyata $5 \%$ dengan menggunakan software Co-Stat. Apabila terdapat beda nyata, maka akan diuji lanjut menggunakan uji Beda Nyata Jujur (BNJ) pada taraf $5 \%$ juga. Hasil penelitian menunjukkan bahwa penambahan ekstrak kecambah kacang hijau berpengaruh nyata terhadap kadar air, kadar protein, kadar abu dan kadar oksalat tepung talas. Perlakuan konsentrasi ekstrak kecambah kacang hijau $40 \%$ direkomendasikan sebagai perlakuan terbaik, yang menghasilkan tepung talas dengan karakteristik sebagai berikut: kadar air $(10,53 \%)$, kadar abu $(5,24 \%)$, kadar protein $(3,84 \%)$, kadar kalsium oksalat $(0,0268 \%)$, daya serap air $(87,42 \%)$, dan nilai $L(88,14)$ tepung talas termodifikasi.
\end{abstract}

Kata kunci: tepung, talas, enzim, kecambah kacang hijau

\section{PENDAHULUAN}

Tepung merupakan partikel padat yang berbentuk butiran halus bahkan sangat halus tergantung pada pemakaiannya. Tepung biasanya digunakan untuk bahan baku industri, keperluan penelitian, maupun dipakai dalam kebutuhan rumah tangga, misalnya membuat kue dan roti. Tepung dibuat dari berbagai jenis bahan nabati, yaitu dari bangsa padi-padian, umbi-umbian, akar-akaran, atau sayuran yang memiliki zat tepung atau pati atau kanji (Wibowo, 2012).Tepung terigu merupakan tepung hasil pengolahan biji gandum yang umum digunakan sebagai bahan baku berbagai produk pangan (BPS, 2000). Nilai impor tepung terigu sebagai komoditi pangan sumber karbohidrat terus meningkat dari tahun ke tahun. Oleh karena itu, upaya pemanfaatan sumber pangan lokal yang tinggi karbohidrat sebagai bahan baku pengolahan tepung perlu dilakukan, salah satunya adalah pemanfaatan umbi talas.

Talas merupakan tanaman penghasil karbohidrat yang tinggi yang memiliki peranan 
cukup baik, tidak hanya sebagai sumber bahan pangan dan bahan baku industri tetapi juga untuk pakan ternak. Kendala pengolahan talas sebagai bahan pangan adalah tingginya kandungan oksalat sehingga memerlukan penanganan agar kandungan oksalat pada talas dapat tereduksi. Salah satu cara untuk mereduksi oksalat adalah dengan perendaman talas di dalam larutan $\mathrm{NaCl}$. Dengan tereduksinya kandungan oksalat pada talas maka akan menghasilkan sumber pangan yang dapat dijadikan sebagai alternatif pangan Indonesia (Marliana, 2011).

Talas memiliki potensi untuk dapat digunakan sebagai bahan baku tepungtepungan karena memiliki kandungan pati yang tinggi, yaitu sekitar $70-80 \%$. Tepung talas memiliki ukuran granula pati yang kecil, yaitu sekitar 0.5-5 mikron (Koswara, 2010). Akan tetapi, kandungan protein tepung talas yang sedikit yaitu 0,69\% (Ridal, 2003) akan mempengaruhi karakteristik tepung talas. Selain kandungan protein, kandungan lemak pada talas juga dapat mempengaruhi aroma dan masa simpan talas. Tepung yang berkadar lemak tinggi, tidak tahan lama cepat bau tengik akibat lemak yang ada dalam bahan (Suarni dkk., 2006). Berdasarkan sifat kimia tepung talas, beberapa diantaranya belum memenuhi Standar Nasional Indonesia untuk tepung terigu. Salah satunya yaitu kadar abu, kadar abu tepung talas yakni $1,28 \%$ (Ridal, 2003) sehingga tidak memenuhi mutu SNI yang menerangkan kadar abu maksimal adalah $0,7 \%$. Untuk memperbaiki karakteristik dari tepung, talas maka perlu dilakukan modifikasi tepung sehingga mendapatkan tepung yang memiliki karakteristik tepung yang lebih baik.

Modifikasi tepung adalah salah satu cara untuk memperbaiki kualitas dari tepung talas biasa. Modifikasi tepung dapat dilakukan dengan bermacam-macam cara, antara lain adalah modifikasi dengan cara memanfaatkan enzim untuk mendapatkan mutu dan kualitas dari tepung yang lebih baik. Modifikasi enzimatik dapat dilakukan dengan menggunakan enzim a-amilase dari kecambah kacang hijau. Kelebihan memanfaatkan bahan sumber enzim tersebut, karena mengandung nutrisi yang tinggi dan anti oksidan yang bermanfaat terhadap kesehatan dan bahan tepung termodifikasi yang dihasilkan bebas dari residu kimia (Suarni dkk., 2007).

Berbagai macam penelitian tentang modifikasi tepung secara enzimatis telah dilakukan. Salah satunya yaitu penelitian oleh Ma'rufah, Ratnani, dan Riwayati (2016) yaitu dengan memodifikasi tepung biji nangka secara enzimatis dengan menambahkan ekstrak kecambah kacang hijau. Hasil penelitian ini menunjukkan bahwa penambahan ekstrak kecambah kacang hijau pada tepung biji nangka berpengaruh terhadap karakteristik dari tepung biji nangka. Hasil penelitian tersebut menunjukkan bahwa penambahan ekstrak kecambah kacang hijau $35 \%$ memberikan presentase enzim a-amilase yang optimum, sehingga dapat menambah kandungan protein pada tepung biji nangka yang awalnya hanya $10,3 \%$ menjadi $14,3 \%$.

Penelitian tentang modifikasi tepung secara enzimatis juga dilakukan oleh Suarni, Harlim, Upe, dan Patong (2006) yaitu dengan melakukan penambahan kecambah kacang hijau kedalam tepung jagung. Dari penelitian tersebut diperoleh formasi bahwa penambahan kecambah kacang hijau 20\% menghasilkan tepung termodifikasi yang terbaik dengan pertimbangan kadar proteinnya meningkat dari $7,89 \%$ menjadi $15,48 \%$. Selain meningkatkan protein, penambahan kecambah kacang hijau juga dapat menurunkan kadar abu (dari $1,12 \%$ menjadi 0,69\%) dan kadar serat (dari 1,29\% menjadi 0,66\%) sehingga dapat mempengaruhi karakteristik tepung jagung menjadi lebih baik. Penelitian tentang modifikasi tepung talas masih terbatas. Oleh karena itu, penelitian tentang pengaruh konsentrasi ekstrak kecambah kacang hijau terhadap sifat fisik dan kimia tepung talas sangat penting dilakukan.

\section{BAHAN DAN METODE}

\section{Bahan dan Alat}

Bahan yang digunakan dalam penelitian ini adalah talas kimpul segar, kecambah kacang hijau, air bersih, aquades, $\mathrm{NaCl}$, NaoH, dan HCL. 
Versi Online:

http://www.profood.unram.ac.id/index.php/profood e-ISSN: 2443-3446

Alat yang digunakan dalam penelitian ini adalah timbangan analitik, baskom, cabinet dryer, blender tepung, ayakan 80 mesh, sendok pengaduk, kain saring, panci, loyang, spatula, cawan, oven, alumunium foil, plastic wrap, tabung sentrifuse, tabung reaksi, rak tabung rekasi, pipet ukur, tisu, label, sentrifuse, inkubator, penangas air, labu takar, spektrofotometer, color solid dan labu tetes.

\section{Metode}

Metode yang digunakan dalam penelitian ini adalah metode eksperimental yang dilaksanakan di laboratorium.

\section{Pelaksanaan Penelitian :}

Pembuatan Tepung Talas

\section{a. Persiapan bahan}

Bahan baku yang digunakan adalah umbi talas kimpul segar $10 \mathrm{~kg}$ yang dibeli di pasar Mandalika. Talas kimpul yang digunakan adalah talas yang cukup tua yaitu dipanen setelah berumur antara 7-9 bulan dan ditandai dengan mengeringnya daun. Umbi talas yang dipilih adalah yang baik dan bebas dari penyakit dan cacat atau luka goresan.

\section{b. Pengupasan dan pengirisan}

Pengupasan umbi untuk memisahkan antara kulit dan daging umbinya dilakukan dengan menggunakan pisau. Selanjutnya dilakukan pengirisan bertujuan untuk mempermudah proses pengeringan bahan.

\section{c. Perendaman dan pencucian}

Perendaman dilakukan dengan menggunakan air garam ( $\mathrm{NaCl} 10 \%)$ selama 60 menit untuk mengurangi kandungan kalsium oksalat yang ada pada umbi talas.

\section{d. Pengeringan}

Proses pengeringan dilakukan dengan menggunakan Cabinet Dryer dengan suhu $60^{\circ} \mathrm{C}$ selama 6 jam. Pada waktu proses pengeringan irisan-irisan talas dibolak balik secara berkala agar dihasilkan pengeringan yang merata pada bahan.

\section{e. Penghancuran/penepungan}

Hasil dari proses pengeringan berupa keripik-keripik talas yang kemudian dihancurkan menggunakan alat blender tepung.

\section{Pro Food (Jurnal IImu dan Teknologi Pangan) \\ Vol 6 No. 1 Mei 2020 \\ ISSN: 2443-1095}

\section{f. Pengayakan}

Untuk mendapatkan ukuran tepung yang merata dan sesuai dengan persyaratan, maka dilakukan pengayakan dengan menggunakan ayakan 80 mesh.

\section{Pembuatan Ekstrak Kecambah Kacang Hijau}

a. Persiapan bahan

Bahan yang digunakan adalah 400 gram kecambah kacang hijau yang dibeli di pasar Mandalika. Kecambah kacang hijau yang digunakan yaitu kecambah yang berumur 3 hari karena kecambah tersebut memiliki aktivitas enzim terbanyak (Suarni, 2007).

\section{b. Pencucian}

Kecambah kacang hijau dibersihkan dengan cara melepas kulit luarnya, lalu dilakukan pencucian untuk memisahkan antara kecambah kacang hijau dengan kotorankotoran yang masih menempel pada kecambah kacang hijau.

\section{c. Penghancuran}

Penghancuran kecambah kacang hijau dilakukan dengan menggunakan blender. Kecambah kacang hijau yang telah bersih kemudian dimasukkan kedalam blender dan ditambahkan aquades dengan perbandingan $1: 1$.

\section{d. Penyaringan}

Proses penyaringan dilakukan dengan menggunakan kain saring atau kain blacu. Proses penyaringan dilakukan untuk mendapatkan ekstak kecambah kacang hijau.

\section{Pembuatan Tepung Talas Termodifikasi a. Persiapan bahan}

Bahan yang digunakan adalah tepung talas dan ekstrak kecambah kacang hijau.

\section{b. Pencampuran}

Pencampuran dimulai dengan menimbang sebanyak $125 \mathrm{~g}$ tepung talas, kemudian ditambahkan konsentrasi ekstrak kecambah kacang hijau sesuai perlakuan yaitu $0 \%$ (0 gram), 10\% (12,5 gram), 20\% (25 gram), 30\% (37,5 gram), dan 40\% (50 gram).

\section{c. Inkubasi}

Proses inkubasi bertujuan untuk berlangsungnya proses enzimatis dalam 
Versi Online:

http://www.profood.unram.ac.id/index.php/profood e-ISSN: 2443-3446

tepung. Proses inkubasi dilakukan $2 \times 24$ jam pada suhu $30^{\circ} \mathrm{C}$. Proses inkubasi ini dilakukan dengan menggunakan alat inkubator dengan pengaturan suhu $30^{\circ} \mathrm{C}$ dan waktu inkubasi selama $2 \times 24$ jam.

\section{d. Pengeringan}

Selanjutnya dilakukan pengeringan tepung dengan menggunakan Cabinet Dryer pada suhu $60^{\circ} \mathrm{C}$ selama 2 jam.

\section{f. Pengayakan}

Untuk mendapatkan ukuran tepung yang merata dilakukan pengayakan dengan menggunakan ayakan 80 mesh.

\section{Rancangan Percobaan}

Rancangan yang digunakan dalam penelitian ini adalah Rancangan Acak Lengkap (RAL) dengan percobaan faktor tunggal yaitu penambahan kecambah kacang hijau yang terdiri dari 5 perlakuan konsentrasi sebagai berikut:

$$
\begin{aligned}
& K 1=0 \% \\
& K 2=10 \% \\
& K 3=20 \% \\
& K 4=30 \% \\
& K 5=40 \%
\end{aligned}
$$

Masing-masing perlakuan diulang sebanyak 4 kali sehingga diperoleh 20 unit. Parameter yang diamati dalam penelitian ini yaitu parameter kimia meliputi kadar air, kadar abu, kadar protein (Sudarmadji dkk, 2007), kadar kalsium oksalat (AOAC, 1984), Daya Serap Air (Ju and Mittal, 1995) dan Uji Warna (Hutching, 1999).

\section{Analisis Data}

Data hasil pengamatan dianalisis dengan menggunakan analisis keragaman atau analysis of variance (ANOVA) pada taraf nyata $5 \%$ dengan software Co-stat. Apabila terdapat beda nyata, maka akan diuji lanjut menggunakan uji Beda Nyata Jujur (BNJ) pada taraf 5\% (Hanafiah, 2010).

\section{HASIL DAN PEMBAHASAN}

\section{Mutu Kimia}

\section{Kadar Air}

Perlakuan konsentrasi kecambah kacang hijau memberikan pengaruh yang berbeda nyata terhadap kadar air tepung talas. Hubungan konsentrasi kecambah kacang hijau dengan kadar air tepung talas yang dihasilkan dapat dilihat pada Gambar 1.

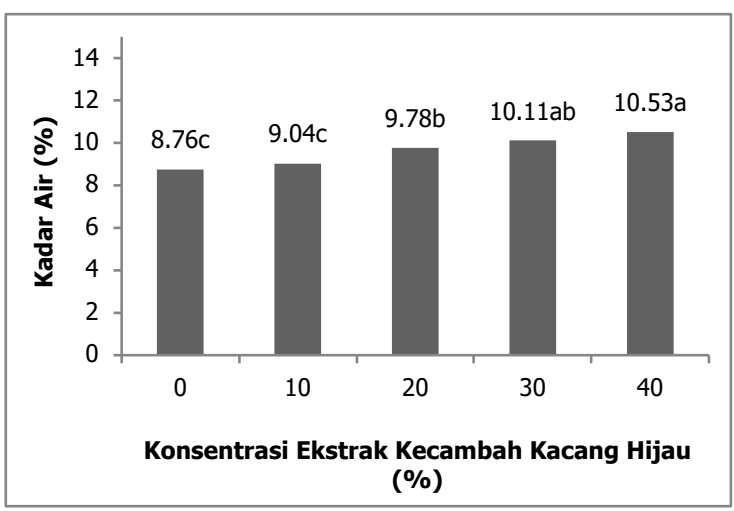

Gambar 1. Pengaruh Konsentrasi Kecambah Kacang Hijau Terhadap Kadar Air TepungTalas

Gambar 1 menunjukkan bahwa semakin tinggi konsentrasi kecambah kacang hijau yang ditambahkan, maka kadar air tepung talas semakin meningkat. Peningkatan kadar air pada tepung talas disebabkan karena tingginya penambahan kecambah kacang hijau, yang mana kecambah kacang hijau yang ditambahkan pada tepung talas tersebut mengandung kadar air yang tinggi yaitu 87,99\% (Fahriyani, 2011).

Selanjutnya kandungan air yang semakin tinggi juga diduga disebabkan karena semakin banyaknya ekstrak kecambah kacang hijauyang ditambahkan untuk memecahpati pada tepung talas. Berdasarkan hasil pengamatan aktivitas enzim alfa-amilase pada kecambah kacang hijau dengan masa pertumbuhan 3 hari yang digunakan dalam penelitian ini didapatkan nilai aktivitas enzim alfa-amilase adalah 33,38 u/ml. Oleh karena itu, diduga semakin tinggi konsentrasi kecambah kacang hijau, maka semakin tinggi pula konsentrasi enzim alfa-amilase yang memecah rantai amilosa. Pati dengan kandungan amilosa yang rendah memiliki kemampuan untuk mengikat air yang tinggi, sebaliknya pati dengan kadar amilosa tinggi memiliki kemampuan untuk mengikat air yang rendah. Rendahnya kemampuan mengikat air disebabkan adanya interaksi antar rantai molekul polimer atau mudah mengalami ikatan 
Versi Online:

http://www.profood.unram.ac.id/index.php/profood e-ISSN: 2443-3446

silang sehingga menghalangi masuknya molekul air (Garcia et al., 1999 dalam Narsito, dkk 2007).

Kadar air sangat berpengaruh terhadap mutu bahan pangan karena dapat mempengaruhi cita rasa, tekstur, aroma dan keawetan dari bahan pangan tersebut (Safitri, 2014). Hasil uji kadar air tepung talas termodifikasi yang diperoleh dalam penelitian ini yaitu $8,76 \%-10,53 \%$ memenuhi standar mutu kadar air produk tepung terigu berdasarkan Standar Nasional Indonesia (SNI) No. 3751: 2009 yaitu kadar air maksimum $14,5 \%(b / b)$.

\section{Kadar Abu}

Perlakuan konsentrasi kecambah kacang hijau memberikan pengaruh yang berbeda nyata terhadap kadar abu. Hubungan konsentrasi kecambah kacang hijau dengan kadar abu tepung talas yang dihasilkan dapat dilihat pada Gambar 2.

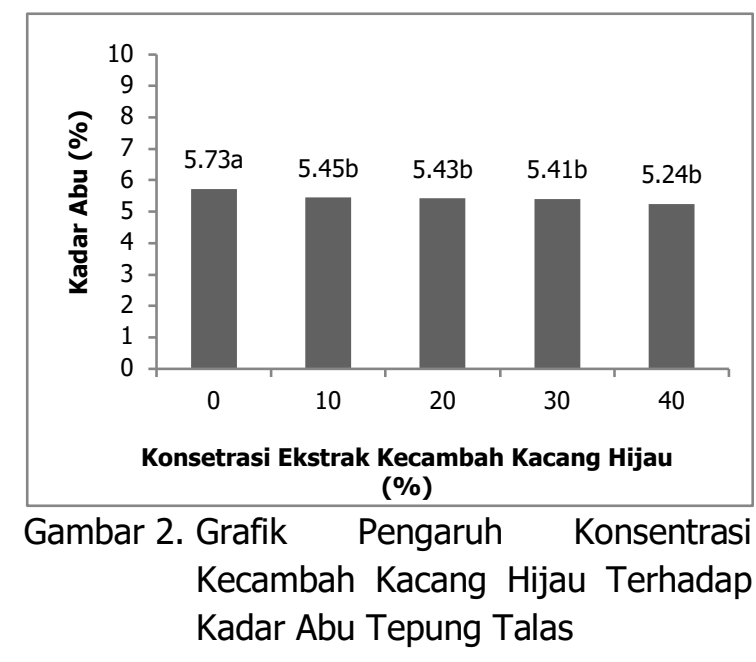

Berdasarkan Gambar 2, ditunjukkan bahwa penambahan ekstrak kecambah kacang hijau kedalam tepung talas menyebabkan kadar abu tepung semakin menurun. Keadaan ini kemungkinan disebabkan oleh adanya perombakan senyawa-senyawa kimia yang disebabkan karena adanya proses enzimatis selama proses pengolahan (Suarni, 2007). Penurunan kadar abu juga dipengaruhi oleh kandungan kadar air pada produk. Kandungan kadar air pada tepung talas termodifikasi cukup tinggi yaitu $8,76 \%$ sampai $10,53 \%$.
Pro Food (Jurnal IImu dan Teknologi Pangan)

Vol 6 No. 1 Mei 2020

ISSN: 2443-1095

Tingginya kadar air ini kemungkinan menyebabkan semakin tinggi kadar air pada produk maka tingkat kadar abu akan semakin menurun. Hal ini sesuai dengan pendapat Suharsono (2008) dalam Khaerul (2017), yang menyatakan bahwa tingginya kandungan mineral di dalam bahan pangan dapat berinteraksi dengan unsur hidrogen sehingga daya kelarutan mineral pada bahan pangan tersebut akan meningkat.

Kadar abu tepung talas termodifikasi dengan perlakuan konsentrasi kecambah kacang hijau yang dihasilkan dalam penelitian ini yaitu berkisar dari 5,24\% sampai 5,73\% tidak memenuhi standar mutu produk tepung terigu yang digunakan sebagai acuan penelitian ini dengan SNI 3751:2009 yaitu kadar abu maksimum $0,7 \%$.

\section{Kadar Protein}

Perlakuan konsentrasi kecambah kacang hijau memberikan pengaruh yang berbeda nyata terhadap kadar protein tepung talas. Hubungan konsentrasi kecambah kacang hijau dengan kadar protein tepung talas yang dihasilkan dapat dilihat pada Gambar 3.

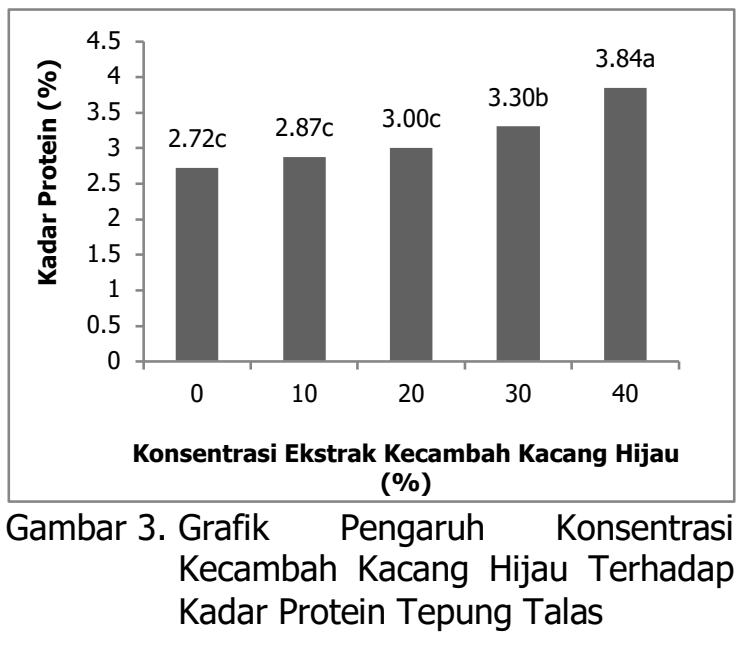

Gambar 3 menunjukkan bahwa semakin tinggi penambahan kecambah kacang hijau maka kadar protein tepung talas semakin meningkat. Kadar protein tepung talas termodifikasi tanpa penambahan ekstrak kecambah kacang hijau yaitu 2,72\%, sedangkan kadar protein tepung talas yang ditambahkan ekstrak kecambah kacang hijau meningkat pada semua perlakuan. Hal ini 
Versi Online:

http://www.profood.unram.ac.id/index.php/profood e-ISSN: 2443-3446

diduga disebabkan karena ekstrak kecambah kacang hijau memiliki kandungan protein yang cukup tinggi yaitu 38,54\% (PERSAGI, 2013). Pendapat ini sesuai dengan pernyataan Suarni (2007) yaitu proses enzimatis dengan aamilase kecambah kacang hijau dapat meningkatkan kadar protein tepung termodifikasi yang disebabkan oleh adanya penambahan kecambah kacang hijau yang juga mengandung protein tinggi. Selain itu protein merupakan juga komponen dari enzim, sehingga apabila jumlah enzim meningkat dengan meningkatnya jumlah kecambah yang ditambahkan maka kadar protein dalam tepung juga akan meningkat.

Kadar protein tepung talas yang diperoleh dalam penelitian ini yaitu 2,72\% sampai $3,84 \%$. Kadar protein tepung dalam talas ini tergolong rendah dan tidak memenuhi syarat standar mutu produk tepung terigu dengan SNI 3751: 2009 yang digunakan sebagai acuan dalam penelitian ini karena standar untuk kandungan protein tepung terigu minimum $7,0 \%$.

\section{Kadar Kalsium Oksalat}

Perlakuan konsentrasi kecambah kacang hijau memberikan pengaruh yang berbeda nyata terhadap kadar kalsium oksalat. Hubungan konsentrasi kecambah kacang hijau dengan kadar kalsium oksalat tepung talas yang dihasilkan dapat dilihat pada Gambar 4.

Berdasarkan data pada Gambar 4, semakin tinggi konsentrasi kecambah kacang hijau yang ditambahkan maka kadar kalsium oksalat semakin meningkat. Hal ini kemungkinan berkaitan dengan adanya kandungan kalsium dalam kecambah kacang hijau yaitu 1729,17 mg/100 gram berat kering. Oksalat pada tepung talas akan mengikat kalsium yang ada pada kecambah kacang hijau. Hal ini sesuai dengan pendapat Agustin (2017) bahwa oksalat dapat bergabung (berikatan) dengan kalsium utnuk membentuk senyawa kompleks yang lebih larut. Selain itu, jika jumlah kalsium dalam bahan mengalami kenaikan maka kadar kalsium oksalat juga cenderung akan mengalami kenaikan. Hal ini sesuai dengan pendapat Ardhian dan Indriyani
Pro Food (Jurnal Ilmu dan Teknologi Pangan)

Vol 6 No. 1 Mei 2020

ISSN: 2443-1095

(2013) bahwa kalsium oksalat adalah hasil dari pengikatan kalsium oleh sebagian oksalat tidak terlarut sehingga membentuk kalsium oksalat.

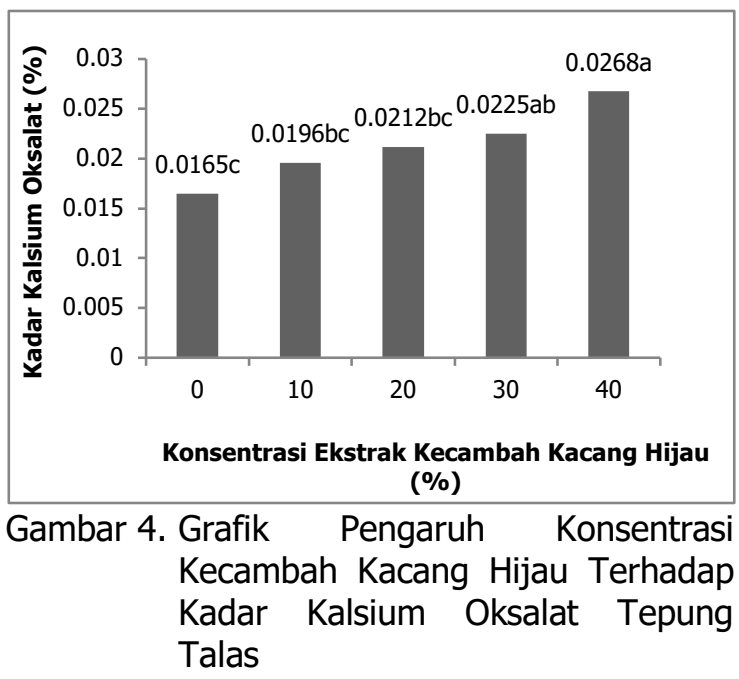

Berdasarkan hasil penelitian ini, kadar kalsium oksalat dalam tepung talas yang dihasilkan dengan penambahan ekstrak kecambah kacang hijau masih aman dan layak untuk dikonsumsi karena kadar kalsium oksalat tersebut kurang dari batas maksimum yang dipersyaratkan. Menurut pendapat AgyirSackey dan Sefa-Dedeh (2004), batas ambang kalsium oksalat dalam bahan pangan agar layak dan aman dikonsumsi adalah 710 ppm atau $0,071 \%$.

\section{Mutu Fisik}

\section{Daya Serap Air}

Perlakuan konsentrasi kecambah kacang hijau memberikan pengaruh yang berbeda nyata terhadap daya serap air. Hubungan konsentrasi kecambah kacang hijau dengan daya serap air tepung talas yang dihasilkan dapat dilihat pada Gambar 5.

Daya serap air pada tepung berkaitan dengan kemampuan tepung untuk menyerap dan menahan sejumlah air sampai batas maksimal tanpa pencampuran (mixing) tambahan guna mengembangkan adonan. Daya serap air berkaitan dengan komposisi granula dan sifat fisik tepung setelah ditambahkan dengan air (Elliason, 2004). Gambar 5 menunjukkan bahwa semakin tinggi penambahan konsentrasi kecambah kacang hijau yang diberikan maka daya serap air 
Versi Online:

http://www.profood.unram.ac.id/index.php/profood e-ISSN: 2443-3446

tepung talas semakin menurun. Hal ini kemungkinan disebabkan oleh adanya penurunan kemampuan tepung dalam mengikat air sehingga kapasitas air yang ditampung dalam tepung menurun. Turunnya kemampuan tepung dalam mengikat air disebabkan oleh ekstrak kecambah kacang hijau yang ditambahkan terlebih dahulu dalam tepung sehingga terjadi penurunan daya ikat tepung. Hal ini sesuai dengan hasil penelitian Manna (1995) yaitu tepung jagung yang diberi suplemen enzim amilase dapat menurunkan kapasitas ikat air dari pati bahan tersebut.

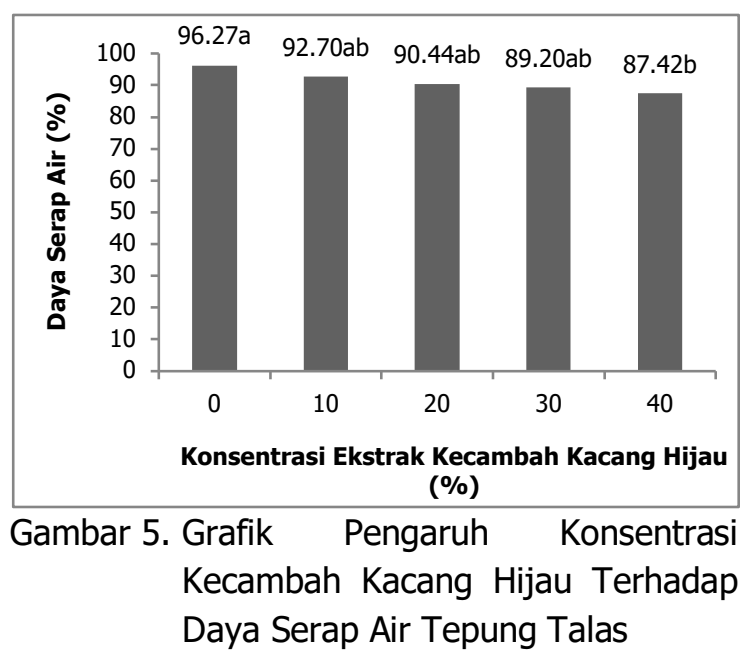

Nilai daya serap air tepung talas termodifikasi yang diperoleh dalam penelitian ini berkisar $87,42 \%-96,27 \%$. Tingginya daya serap air ini dihubungkan dengan kemampuan produk untuk mempertahankan tingkat kadar air terhadap kelembaban lingkungan dan peranan gugus hidrofilik pada susunan molekulnya (Afrianti, 2004).

\section{Nilai L (Lightning)}

Penentuan mutu bahan termasuk tepung pada umumnya sangat bergantung pada beberapa faktor diantaranya tingkat kecerahan (Nilai L). Proses pengolahan akan mempengaruhi warna produk pangan yang dihasilkan (Winarno, 1986). Perlakuan konsentrasi kecambah kacang hijau memberikan pengaruh yang berbeda nyata terhadap nilai L. Hubungan konsentrasi kecambah kacang hijau dengan nilai $L$ tepung talas yang dihasilkan dapat dilihat pada Gambar 6.

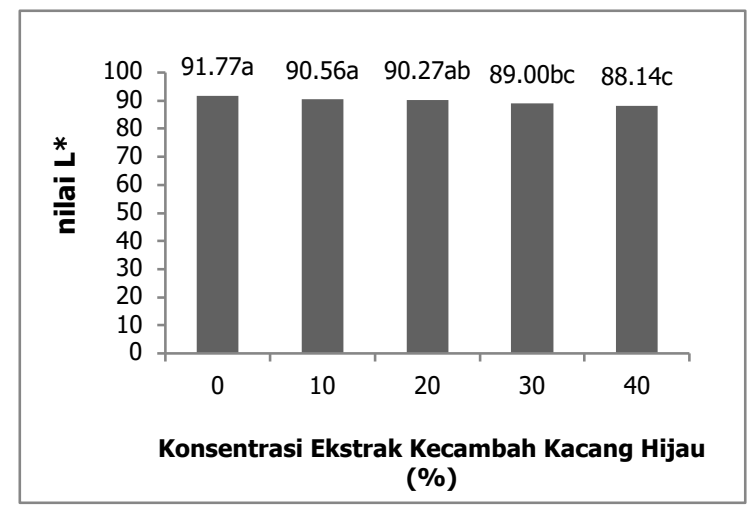

Gambar 6. Grafik Pengaruh Konsentrasi Kecambah Kacang Hijau Terhadap Nilai L Tepung Talas

Gambar 6 menunjukkan bahwa semakin tinggi konsentrasi ekstrak kecambah kacang hijau yang ditambahkan ke dalam tepung talas maka tingkat kecerahan tepung (nilai L) semakin menurun. Menurunnya nilai L kemungkinan besar disebabkan oleh warna ekstrak kecambah kacang hijau yang ditambahkan kedalam tepung, karena warna ekstrak kecambah kacang hijau adalah putih keabu-abuan. Nilai $L$ tertinggi diperoleh pada tepung dengan perlakuan tanpa penambahan ekstrak kecambah kacang hijau yaitu 91,77, sedangkan nilai $\mathrm{L}$ yang terendah diperoleh pada tepung dengan perlakuan dengan penambahan ekstrak kecambah kacang hijau $40 \%$.

\section{KESIMPULAN}

Berdasarkan hasil analisis dan pembahasan yang terbatas pada ruang lingkup penelitian ini, maka dapat ditarik kesimpulan sebagai berikut: (1) perlakuan penambahan ekstrak kecambah kacang hijau memberikan pengaruh yang berbeda nyata terhadap kadar air, kadar abu, kadar protein, kadar kalsium oksalat, daya serap air, dan tingkat kecerahan (nilai L) tepug talas; (2) Semakin tinggi penambahan ekstrak kecambah kacang hijau maka kadar protein tepung talas semakin meningkat; (3) Kadar protein tepung talas tertinggi yaitu $3,84 \%$ didapatkan pada 
Versi Online:

http://www.profood.unram.ac.id/index.php/profood e-ISSN: 2443-3446

perlakuan ekstrak kecambah kacang hijau $40 \%$. (4) Rata-rata kadar air tepung talas pada semua perlakuan yaitu $8,76 \%-10,53 \%$ memenuhi standar kadar air tepung berdasarkan SNI tepung terigu No. 3751 : 2009 yaitu maksimum 14,5\%; (5) Kadar kalsium oksalat pada semua perlakuan yaitu berkisar 0,0165\%-0,0268\% berada dibawah batas maksimum kadar kalsium oksalat dalam bahan yang layak dikonsumsi yaitu $0,071 \%$; (6) Kadar abu tepung talas yaitu 2,72\%-3,84\% pada semua perlakuan tidak memenuhi dari SNI tepung terigu No. 3751:2009, dimana kadar abu tepung terigu maksimal yaitu $0,7 \%$.

\section{DAFTAR PUSTAKA}

Afrianti, H. 2004. Pengertian Destilasi dari Hasil Fermentasi. Forum Sains: Jakarta.

Agustin, R., Teti, E. dan Agustin, KW.2017. Penurunan Oksalat pada Proses Perendaman Umbi Kimpul (Xanthosoma sagittifolium) di Berbagai Konsentrasi Asam Asetat. Jurnal Teknologi Pertanian 18(3): 191-200.

Agyr-Sackey, EK. and Sefa-Dedeh, S. 2004. Chemical Composition and the Effect of Processing an Oxalate Content of Cocoyam Xanthosoma sagittifolium and Colocasia esculenta L. J. Food Chemsitry 85:479-487.

AOAC. 1984. Official Methods of Analysis. Association of Official. Agricultural Chemists. Washington DC.

Ardhian, D. dan Indriyani, S. 2013. Kandungan Oksalat Umbi Porang (Amorphophallus Muelleri Blume) Hasil Penanaman dengan Perlakuan Pupuk $\mathrm{P}$ dan $\mathrm{K}$. Biotropika: Jorrnal of Tropical Biology Universitas Brawijaya 1(2): 53-56.

Badan Pusat Statistik (BPS). 2000. Pemanfaatan tepung terigu pada berbagai produk olahan. Jakarta: BPS.

Badan Standardisasi Nasional (BSN). 2009. SNI 3751:2009 Tepung Terigu sebagai Bahan Makanan. BSN. Jakarta.

Eliasson, C. 2004. Starch in Food, Structure, Function, and Application. Woodhead Publishing Limited Cambridge England.

Fahriyani, I. 2011. Pemanfaatan Kecambah Kacang Hijau Dalam Formulasi Bubur
Pro Food (Jurnal IImu dan Teknologi Pangan)

Vol 6 No. 1 Mei 2020

ISSN: 2443-1095

Susu Instan Sebagai Alternatif Makanan Pendamping Air Susu Ibu (MP-ASI). IPB : Bogor

Hanafiah, KA. 2010. Rancangan Percobaan Teori dan Aplikasi. Edisi Ketiga. Jakarta: Rajawali Press.

Hutching, JB. 1999. Food Color and Apearance. Aspen publisher Inc., Maryland.

Ju, J. dan Mittal, GS. 1995. Physical Properties of Various Starch-based Fat Substitutes. Journal of Processing and Preservation 19: 361-383.

Khaerul. 2017. Pengaruh Kombinasi Tepung Terigu dan Bubur Okra ( Abelmoschus esculentus L) Terhadap Mutu dan Aktivitas Antioksidan Mie Basah. Skripsi. Fakultas Teknologi Pangan Dan Agroindustri. Universitas Mataram.

Koswara, S. 2010. Teknologi Pengolahan Umbi-Umbian Bagian 2: Pengolahan Umbi Porang. Bogor: IPB.

Ma'rufah, A., Ratnani, RD. dan Riwayati, I. 2016. Pengaruh Modifikasi Secara Enzimatis Menggunaka Enzim a-Amilase Dari Kecambah Kacang Hijau Terhadap Karakteristik Tepung Biji Nangka (Artocarpus heterophyllus Lamk). Jurnal inovasi teknik kimia, 1(2): 65-70.

Magomya, AM., Kubmarawa, DN., dahi, JA. dan Yebpella, GG. 2014. Determination of plant proteins via the Kjeldahl method and amino acid analysis: A comparative study. International journal of scientific \& technology research 3(4): 68-72.

Manna, KM., Naing, KM. and Hia PE. 1995. Amylase Activity Of Some Roots And Sprouted Cereals And Beans. Food and Nutrition Bulletin 16 (2): 1-5

Marliana, E. 2011. Karakterisasi Dan Pengaruh Nacl Terhadap Kandungan Oksalat Dalam Pembuatan Tepung Talas Banten. Skripsi. Fakultas Teknologi Pertanian. Institut Pertanian Bogor.

Narsito, SW., Widyanngsih, TD. dan Ekasari D. 2007. Modifikasi Pati Alami dan Pati Hasil Pemutusan Rantai Cabang dengan Perlakuan Fisik/ Kimia untuk Meningkatkan Kadar Pati Resisten pada Pati Beras. Fakultas Teknologi Pertanian. Universitas Brawijaya. Malang. 
Versi Online:

http://www.profood.unram.ac.id/index.php/profood e-ISSN: 2443-3446

Persatuan Ahli Gizi Indonesia (PERSAGI). 2009. Kamus IImu Gizi. Jakarta: PT. Kompas Media Nusantara.

Purwono dan Hartono. R. 2005. Kacang Hijau. Penerbit Penebar Swadaya. Jakarta.

Ridal, S. 2003. Karakteristik sifat Fisiko-Kimia tepung dan pati talas (Colocasia esculenta) dan kimpul (Xanthosoma sp.) dan uji penerimaan a-amilase terhadap patinya. Skripsi. Fakultas Teknologi Pertanian. IPB. Bogor. 60 hal.

Rossi, AM., Villarreal, M., Juarez, MO. and Samman, NC. 2004. Nitrogen contents in food: A comparison between the Kjeldahl and hach methods. The Journal of Argentine Chemical Society 92(4/6): 99-108.

Safitri, F. 2014. Substitusi Buah Sukun (Artocapus altilis Forst) Dalam Pembuatan Mie Basah Berbahan Dasar Tepung Gaplek Berprotein. Skripsi. Universitas Kristen Satya Wacana. Salatiga.

Siener, RR., Honow, S., Voss, A. Seidler and Hesse, A. 2006. Oxalate content of cereals and cereals product. J. Agric Food Chem, 54(8): 3008-30011.

Suarni, Harlim, T., Upe, A., dan Patong R. 2007. Pengaruh Modifikasi Enzimatik (aAmilase) terhadap Viskositas dan Komposisi Karbohidrat Tepung Jagung. Indo. J. Chem 7(1): 218-222.

Suarni, Ubbe, U., Upe, A., dan Harlim, T. 2006. Modifikasi Tepung Jagung dengan Enzim (a - Amilase) dari Kecambah Kacang Hijau. Prosiding Seminar Nasional Teknologi Inovatif Pascapanen Untuk Pengembangan Industri Berbasis Pertanian: 246-252.

Sudarmadji, B., Bambang H. dan Suhardi. 2007. Analisis Bahan Makanan dan Pertanian. Kanisius. Yogyakarta.

Sudarmadji, B., Haryono dan Suhardi. 1997. Prosedur Analisa Bahan Makanan dan Pertanian. Fakultas Pertanian. Universitas Gadjah Mada. Yogyakarta.

Sutrisno, K. 2010. Teknologi Pengolahan Umbiumbian Bagian 1: Pengolahan Umbi Talas. Bogor Agricultural University, Bogor.
Pro Food (Jurnal IImu dan Teknologi Pangan)

Vol 6 No. 1 Mei 2020

ISSN: 2443-1095

Suwardi. 2011. Analisa Kadar Oksalat Dalam Daun Bayam Yang Sudah Dimasak Dengan Metode Spektrofotometri UV. Universitas Islam Negeri Sultan Syarif Kasim Riau. Pekanbaru.

Wibowo, D. 2012. Tepung Menurut Djoni Wibowo. Skripsi. Universitas. BINUS Jakarta.

Winarno, FG. 1986. Enzim Pangan. Ed. III. PT. Gramedia. Jakarta. hal. 18-59. 